RESEARCH PAPER RP821

Part of Journal of Research of the National Bureau of Standards, Volume 15, August 1935

\title{
ANALYSIS OF TEXTILES FOR CELLULOSE-ACETATE RAYON, SILK, REGENERATED-CELLULOSE RAYON, COTTON, AND WOOL
}

\author{
By Ralph T. Mease and Daniel A. Jessup
}

ABSTRACT

A quantitative method for the determination of cellulose-acetate rayon, silk, regenerated-cellulose rayon, cotton, and wool in textiles containing two or more of these fibers is described. The textile is first extracted with carbon tetrachloride, and desized with a starch and protein hydrolyzing enzyme and by washing. Acetate rayon (acetone-soluble type) is removed with acetone, and silk and regenerated-celıulose rayons with solutions of calcium thiocyanate of specific gravity 1.20 and 1.36, respectively. Cotton and wool are determined either by removal of cotton with aluminum chloride and heat to leave the wool, or by dissolving the wool in potassium-hydroxide solution to leave the cotton. The method gives the percentage of each of the fibers present in the mixture to within 2 percent of the weight of the specimen analyzed.

\section{CONTENTS}

I. Introduction

II. Purification of fibers

III. Action of reagents on purified fibers

IV. Procedure for the analysis of fiber mixtures.

1. Preparation of specimen for analysis_...

2. Drying and weighing of specimen

3. Determination of total sizing, finishing, and other nonfibrous materials

4. Determination of cellulose-acetate rayon_.

5. Determination of silk

6. Determination of regenerated-cellulose rayon

7. Determination of wool protein $\ldots$

8. Alternative method for determination of cotton

V. Analysis of specimens of known composition

\section{INTRODUCTION}

The study of methods for the analysis of textiles composed of cotton and wool ${ }^{1}$ has been extended to include mixtures containing, in addition to these fibers, cellulose-acetate rayon ${ }^{2}$ (acetone-soluble type), silk, and regenerated-cellulose rayon, or any two or more of these fibers.

The general procedure in the analysis of fiber mixtures is to eliminate sizing, finishing, and other nonfibrous materials from the mixture and then to remove the different kinds of fibers, one at a time, by suitable reagents. The action (on purified samples of each kind of

\footnotetext{
1 BS J. Research 12, 75 (1934) RP635.

2 The use of the terms rayon, cellulose-acetate rayon, cuprammonium rayon, nitrocellulose rayon, and viscose rayon used in this paper is in accordance with definitions given in Tentative Definitions and Terms Relating to Textile Materials, Am. Soc. Testing Materials designation D123-33T. Proc. Am. Soc. Testing
} Materials, 33, part I, 944 (1933). 
fiber) of a typical desizing treatment and of the reagents which appeared to be useful for the separation of the kinds of fibers, was determined in the present work. Mixtures of known composition were analyzed in order to demonstrate the practicability of a proposed standard procedure and to indicate the accuracy attainable. The results are given in this paper.

\section{PURIFICATION OF FIBERS}

The silk was prepared from thrown silk by immersion for 20 to 30 minutes in a boiling 0.2 -percent solution of neutral soap. The silk was rinsed with successive portions of hot distilled water until the rinse water appeared to be free of soap, immersed for 20 minutes in a boiling 0.1 -percent solution of sodium carbonate, rinsed, dried, extracted for 6 hours in a soxhlet extraction apparatus with ethyl alcohol, and then for 6 hours with ether, air-dried, washed with warm water, and dried.

The cellulose-acetate rayon and the wool were prepared from yarns in the same manner, except that the temperature of the soap and sodium-carbonate solutions used for the wool was kept at approximately $70^{\circ} \mathrm{C}$, and the cellulose-acetate rayon was not extracted with alcohol and ether.

The regenerated-cellulose rayons used in this study included the following four types: nitrocellulose, cuprammonium, ordinary viscose, and viscose manufactured by the Lilienfeld ${ }^{3}$ process. These fibers were prepared by extracting successively, for periods of 6 hours each, with ethyl alcohol, diethyl ether, and with a 1-percent aqueous solution of potassium hydroxide; washing with dilute acetic acid, then with distilled water, and drying.

\section{ACTION OF REAGENTS ON PURIFIED FIBERS}

Several organic solvents for grease, oils, and similar materials are effective for the removal of these substances from textile fibers. It is necessary, however, in analytical work to use a solvent which has a negligible effect upon the weight of the purified fibers. Carbon tetrachloride meets this requirement.

A portion of the sizing and finishing materials may consist of substances such as starches, gums, casein, and gelatin, which are insoluble in carbon tetrachloride and must be removed by other asents harmless to the fibers. Mixtures of suitable amylolytic and proteolytic enzymes ${ }^{4}$ are available for the successful desizing of textiles when the sizing material consists of starches and proteins.

To determine the effect of a desizing treatment consisting of a carbon-tetrachloride extraction followed by a malting or enzyme treatment on the purified fibers, 5 -g specimens consisting of approximately equal parts of: (a) purified cellulose-acetate rayon; (b) viscose, nitrocellulose, or cuprammonium rayon; (c) silk; (d) wool; and (e) cotton, or mercerized cotton, were dried for 2 hours at 105 to $110^{\circ} \mathrm{C}$, weighed, and extracted for 2 hours with carbon tetrachloride in a

\footnotetext{
${ }^{3}$ Franz Reinthaler and F. M. Rowe. Artificial Silk, p. 91 (Published (in 1928) by Chapman and Ha 1], Ltd., London).

1933 Yearbook of the American Association of Textile Chemists and Colorists. Alphabetical list of Textile Chemical Specialties, p. 318. (Published June 1934 by the Howes Publishing Co., 440 Fourth Ave., New York.)
} 
soxhlet extraction apparatus. The fibers were air-dried, rinsed with warm water, and immersed in a 2 -percent enzyme solution ${ }^{5}$ at $50^{\circ} \mathrm{C}$; the solution was heated to 65 to $70^{\circ} \mathrm{C}$ and the fibers then kept immersed in the solution for 15 to 30 minutes. The fibers were washed, collected on a bitumen filter, dried, and weighed. The average loss for 10 prepared specimens treated in this manner was less than 0.3 percent of the weight of the fibers, with a maximum loss of 0.4 percent for any of the specimens.

Cellulose-acetate fibers (acetone-soluble type) are readily dissolved by agitating them for 15 minutes in acetone, at room temperature. This treatment has no effect on the weight of the other fibers under consideration and a quantitative separation can readily be effected.

The four remaining kinds of fibers are not so readily separated. However, von Weimarn found that silk $^{6}$ and cellulose ${ }^{7}$ can be dissolved in a concentrated aqueous solution of calcium thiocyanate. The action of this reagent on cellulose fibers was given further consideration by Williams. ${ }^{8}$ McGregor and Fryd ${ }^{9}$ were able to separate viscose rayon from cotton in garnetted waste by using an acidified solution of calcium thiocyanate, which boiled at 122 to $123^{\circ} \mathrm{C}$. Krais and Markert ${ }^{10}$ used a solution of calcium thiocyanate containing $100 \mathrm{~g}$ of the "technical" thiocyanate in $100 \mathrm{ml}$ of solution to dissolve one form of regenerated-cellulose rayon (viscose) and silk in the same operation, to separate them from cotton and wool. No attempt is described, however, to separate silk from the regenerated-cellulose rayons with thiocyanate solutions of concentrations that leave rayon fibers, wool, and cotton practically unattacked. Preliminary experiments in the development of a practical method showed that this could be done.

Purified silk fibers were agitated with solutions of calcium thiocyanate of specific gravities $1.1,1.2,1.3,1.4$, and 1.5 , respectively, at approximately $70^{\circ} \mathrm{C}$ and the time required to effect a filterable solution was noted. Solutions of thiocyanate of specific gravities 1.1 and 1.5, respectively, required approximately 50 minutes; the intermediate concentrations required from 5 to 10 minutes. When insoluble fibers were present, a longer time was required to dissolve silk. A filterable solution and good separation were always obtained when the fibers were well agitated for 1 hour with calcium-thiocyanate solution of specific gravity 1.20. This had little effect on the other fibers. The silk was dissolved when the solution was neutral or made just acid with acetic acid.

The method of Krais and Markert, referred to above, calls for the separation of viscose and cotton from silk and wool with 80-percent sulphuric acid. This does not appear to be practicable, because silk is about as readily soluble as cotton in the acid. Further, the work already reported ${ }^{11}$ shows that sulphuric acid changes the weight of wool.

\footnotetext{
${ }^{5}$ The enzyme mixture used in this work was Degomma D. L., obtained from Röhm \& Haas Co., Phila., $\mathrm{Pa}$.

${ }^{6}$ Ind. Eng. Chem. 19, 109 (1927)

7 Russ. Chem. Soc. 44, 772 (1912); Kolloid-Z. 11, 41 (1912); English translation in Rep. Imp. Ind. Research Inst., Osaka, Japan 4, no. 7, 17 (1923).

$8 \mathrm{~J}$. Soc. Chem. Ind. 40, 221T (1921)

J. Textile Inst. 24, no. 2, T103 (1933)

$10 \mathrm{~J}$. Textile Inst. 23, P213 (1932).

11 BS J. Research 12, 75 (1934) RP635.
} 
The use of calcium-thiocyanate solution for the separation of regenerated-cellulose rayon from cotton and wool was studied. Purified samples of these fibers were prepared for the experiments by cutting the fibers to lengths of about 2 to $4 \mathrm{~mm}$. They were mixed in different combinations and amounts. In one experiment four specimens, each consisting of approximately equal parts by weight of cotton and viscose, were agitated for 45 minutes at $70^{\circ} \mathrm{C}$ with acidified thiocyanate solutions of concentrations having specific gravities $1.30,1.33,1.36$, and 1.38. After the treatment the solutions were filtered and the insoluble material was washed, dried, and weighed. Cotton was recovered with less than 0.5 percent change in weight in the experiment using the concentration of specific gravity 1.36 or 1.38 , but with the two lower concentrations the residue was found to weigh appreciably more, owing to incomplete solubility and removal of viscose rayon.

As stated above, a solution of specific gravity 1.20 dissolved silk without difficulty. It was found that viscose rayon treated with this solution for 1 hour loses less than 1 percent, and when treated for 2 hours, less than 2 percent of its weight. Although higher concentrations than that of specific gravity 1.36 dissolve rayon, this concentration has the advantage of lower viscosity and is more readily filtered than solutions of higher concentrations. Further experiments showed that solutions of specific gravity 1.35 to 1.36 readily dissolve nitrocellulose, cuprammonium, viscose, and Lilienfeld rayons, and that wool, cotton, or mercerized cotton lose less than 2.5 percent of their weight when treated alone for 2 hours. When treated in the presence of soluble fibers the loss is usually less.

When fibers were treated with calcium-thiocyanate solution under conditions such that they dissolved, they first swelled and gradually formed an apparently homogeneous solution. When the fibers were in tightly twisted yarns, the solution did not have free access to the individual fibers. Some of the fibers swelled and coalesced in a way to protect others from the reagent and several hours were required to obtain a homogeneous solution. The time required for solution was lessened when the fibers were well separated and then agitated while they were dissolving.

The calcium-thiocyanate solutions were prepared from a commercial grade of the salt which was not purified for the purpose except by filtering. To prepare solutions of specific gravities 1.20 and 1.36, respectively, approximately $560 \mathrm{~g}$ for a solution of the first concentration and $1,000 \mathrm{~g}$ for the second were dissolved in sufficient distilled water to make 1 liter of each. The solutions were made just acid to litmus with acetic acid. Solutions of calcium thiocyanate used for dissolving silk and regenerated-cellulose fibers may be recovered for subsequent use by diluting them with distilled water to produce a solution of specific gravity of 1.1 or less. This precipitates the dissolved silk protein and cellulose, which will settle to the bottom of the container. The clear liquid is then drawn off and evaporated on the steam bath in a large evaporating dish until the desired density is reached. It is filtered just before use. Solutions repeatedly recovered in this way do not appear to have changed in their solvent effect upon fibers.

As previously indicated, adequate means for keeping the fibers in suspension in the solutions must be provided to prevent the formation 
of masses of fibers which will dissolve slowly. It has been suggested ${ }^{12}$ that the Launder-Ometer ${ }^{13}$ be used to provide the agitation. It was tried in this work both with and without monel-metal balls in the jars containing the thiocyanate solution and fibers. The result was incomplete solution of silk and rayon with masses of swollen fibers attached to the bottom and top of the jar and with considerable damage to cotton and wool when metal balls were used to prevent the formation of masses of fibers.

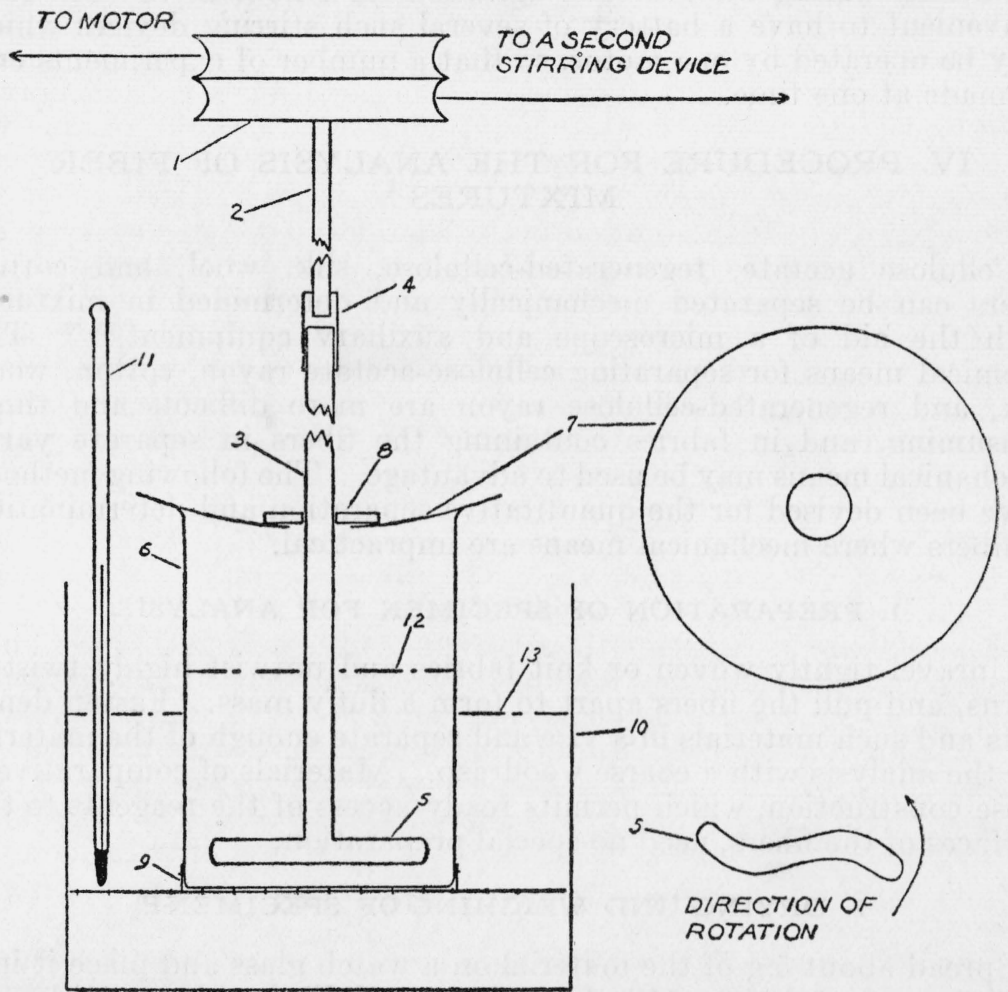

FIGURE 1.-Mechanical stirring device to furnish mechanical action at a controlled temperature when dissolving silk and regenerated-cellulose rayons.
1. Double-grooved pulley.
2. Metal shaft.
3. Glass stirring rod.
4. Rubber joint.
5. Glass stirring fins.
6. 600 -ml beaker.
7. Watch glass with hole.

8. Rubber washer.

9. Wire-screen support.

10. Container for hot water.

11. Thermometer.

12. Level of thiocyanate solution.

13. Water level.

A simple and convenient apparatus that was used successfully for dissolving fibers in the thiocyanate solution is shown in figure 1 . It consists of a water bath for controlling the temperature of the thiocyanate solution within $2^{\circ} \mathrm{C}$, a $600-\mathrm{ml}$ beaker with cover, and

12 See footnote on page 94 of reference 14.

${ }_{13}$ Manufactured by the Atlas Electrical Devices Co., Chicago, Ill.

$811-35-7$ 
an inverted T-shaped glass stirrer, which is operated at 320 to 350 $\mathrm{rpm}$. The fins of the stirrer are bent in the direction opposite the direction of rotation to decrease the tendency of the fibers to become wrapped about them. The beaker is held in place by a form made of wire screen and is covered with a watch glass having a hole in the center through which the stem of the stirrer extends. The watch glass should fit the beaker sufficiently well so that not more than $5 \mathrm{ml}$ of water is lost by evaporation from $200 \mathrm{ml}$ of thiocyanate solution in the beaker during the course of agitation for 1 hour at $70^{\circ} \mathrm{C}$. It is convenient to have a battery of several such stirring devices which may be operated by one motor, so that a number of experiments can be made at one time.

\section{PROCEDURE FOR THE ANALYSIS OF FIBER MIXTURES ${ }^{14}$}

Cellulose acetate, regenerated-cellulose, silk, wool, and cotton fibers can be separated mechanically and determined in mixtures with the aid of a microscope and auxiliary equipment. ${ }^{15}{ }^{16}$ The chemical means for separating cellulose-acetate rayon, cotton, wool, silk, and regenerated-cellulose rayon are more difficult and timeconsuming, and in fabrics containing the fibers in separate yarns mechanical means may be used to advantage. The following methods have been devised for the quantitative separation and determination of fibers where mechanical means are impractical.

\section{PREPARATION OF SPECIMEN FOR ANALYSIS}

Unravel tightly woven or knit fabrics and untwist highly twisted yarns, and pull the fibers apart to form a fluffy mass. Fasten dense felts and such materials in a vise and separate enough of the material for the analysis with a coarse woodrasp. Materials of comparatively loose construction, which permits ready access of the reagents to the surfaces of the fibers, need no special preparation.

\section{DRYING AND WEIGHING OF SPECIMEN ${ }^{17}$}

Spread about $5 \mathrm{~g}$ of the material on a watch glass and place it in a drying oven at 105 to $110^{\circ} \mathrm{C}\left(221\right.$ to $\left.230^{\circ} \mathrm{F}\right)$ for about $1 \frac{1}{2}$ hours. Transfer the specimen while warm to a tared weighing bottle, cover the bottle, and place it in a desiccator to cool. Weigh the bottle and contents. Repeat the drying, weighing at intervals of about $1 / 2$ hour until there is no progressive change in weight of the bottle and contents. All subsequent weighings are made in this manner. Let the weight of the oven-dried specimen be designated $A$.

\footnotetext{
${ }_{14}$ A tentative procedure for the analysis of fiber mixtures based on our preliminary experiments was submitted to Committee D-13 on Textile Materials of the American Society for Testing Materials on April 12, 1933, at the Committee's request, and was published as Tentative Methods for the Identification of Fibers in Textiles and for the Quantitative Analysis of Textiles, Am. Soc. Testing Materials designation D276-33T. Proc. Am. Soc. Testing Materials 33, part I, 931(1933).

15 Edward R. Schwarz, Textiles and the Microscope (published (in 1933), by McGraw-Hill Book Co., Inc., New York).

${ }_{16}$ Paul Heermann und Alois Herzog, Mikroskopische und mechanisch-technische Textiluntersuchungen, 3d ed. (published (in 1931) by Julius Springer, Berlin).

${ }_{17}$ This procedure was followed for all the fibers used in the experiments reported here. A better procedure when analyzing finished textiles of commerce, which may contain substances which harm the fibers or become firmly fixed to them during the drying procedure, is to determine moisture on a sample other than that used for the determination of the different kinds of fibers.
} 


\section{DETERMINATION OF TOTAL SIZING, FINISHING, AND OTHER NONFIBROUS MATERIALS}

(a) Extract the specimen from $(2)^{18}$ in a soxhlet extraction apparatus with carbon tetrachloride for 2 hours. Remove the specimen, allow it to dry, then wash it by agitating it in warm, distilled water, and remove the excess water by squeezing.

(b) Immerse the specimen from (a) in approximately a 0.5 -percent solution of a starch and protein-hydrolyzing enzyme at $50^{\circ} \mathrm{C}\left(122^{\circ} \mathrm{F}\right)$, and squeeze the specimen while it is immersed. Repeat the squeezing for at least 6 times to saturate the fibers with the enzyme solution. The solution is heated to $70^{\circ} \mathrm{C}\left(158^{\circ} \mathrm{F}\right)$ or to the temperature known to be optimum for the enzyme used, and kept at this temperature for 15 minutes or more with the specimen immersed in it. Rinse the specimen at least 12 times in fresh portions of hot distilled water, agitate it well in each rinse water to aid in removing insoluble materials such as china clay, and squeeze it after each rinse. Dry the specimen to constant weight as before. This gives the weight of clean, dry fiber, $B$. The percentage of sizing, finishing, and other nonfibrous materials in the oven-dried specimen, is $100(A-B) / A$.

(c) The purpose of this procedure is to remove all nonfibrous constituents. These include the oils, waxes, dirt, and similar materials associated with the fiber before it is processed and sizing and finishing materials added by the manufacturer. The method described is effective for the removal of the usual natural constituents and starch, clay, some waxes, and nondrying oils. When it is necessary for the analyst to modify the procedure to remove certain nonfibrous materials, the effect of the modified treatment on the weight of clean fibers of the same kinds as those in the specimen should be determined.

\section{DETERMINATION OF CELLULOSE-ACETATE RAYON}

Agitate the specimen from (3) for 15 minutes in about 50 times its weight of acetone at room temperature, and rinse it with two portions of fresh acetone. Remove the specimen and free it of excess acetone by squeezing and permit it to dry. Immerse it in distilled water at about $70^{\circ} \mathrm{C}\left(158^{\circ} \mathrm{F}\right)$, remove the excess water, and dry in the oven as before to constant weight $C$. The percentage of cellulose-acetate rayon, (acetone-soluble type) in the oven-dried specimen, is 100 $(B-C) / A$.

\section{DETERMINATION OF SILK}

Cut the residue of fibers remaining from (4) into lengths of about 2 to $4 \mathrm{~mm}$ with sharp scissors. Agitate the fibers vigorously for 1 hour at $70^{\circ} \mathrm{C}$ in $200 \mathrm{ml}$ of a clear solution of calcium thiocyanate of specific gravity 1.20 to 1.21 at $70^{\circ} \pm 2^{\circ} \mathrm{C}\left(158^{\circ} \mathrm{F}\right)$, made just acid to litmus with acetic acid. Precautions must be taken to prevent evaporation with consequent concentration of the thiocyanate solution during the treatment. Filter the liquid by forming a pad of the insoluble fibers in a small büchner funnel, gooch crucible, or bitumen filter. After a good pad has been formed, combine the portions of the solution, heat it to approximately $70^{\circ} \mathrm{C}$ and filter it through the pad with the aid of suction. Remove the pad from the filter and agitate it well for 5 minutes in $200 \mathrm{ml}$ of fresh thiocyanate solution at $70^{\circ} \mathrm{C}$. Filter,

${ }_{18}$ The numbers in parentheses are citations to determination procedures in section IV. 
wash the fibers with hot distilled water until free of thiocyanate, and dry to constant weight $D$. The percentage of silk in the oven-dried specimen, is $100(C-D) / A$.

\section{DETERMINATION OF REGENERATED-CELLULOSE RAYON}

Pull apart the fibers of the mat left from (5) and if they have been badly felted or twisted together, cut them apart with scissors. Treat the fibers in the same manner as described in (5), but use a solution of calcium thiocyanate of specific gravity 1.35 to 1.36 (at $70^{\circ} \mathrm{C}$ ), made just acid with acetic acid. Obtain the weight $\mathrm{E}$ of the dry fibers remaining from this treatment. The percentage of regeneratedcellulose rayon in the oven-dried specimen, is $100(D-E) / A$.

\section{DETERMINATION OF WOOL PROTEIN}

Immerse the specimen from (6) for 10 minutes in a boiling solution of aluminum chloride prepared by dissolving $9 \mathrm{~g}$ of the hydrated salt $\left(\mathrm{AlCl}_{3} \cdot 6 \mathrm{H}_{2} \mathrm{O}\right)$ in $100 \mathrm{ml}$ of water. Remove the specimen from the solution; allow the excess liquid to drain, or lightly squeeze the specimen. Heat it at 105 to $110^{\circ} \mathrm{C}$ (221 to $\left.230^{\circ} \mathrm{F}\right)$, until the cotton has become brown and brittle -2 hours is usually sufficient, but it is often convenient to leave the specimen overnight in an electric oven at this temperature. Immediately on removing the specimen from the oven, place it on a no. 100 sieve, and rub the fibers with sufficient pressure to powder the cellulose and pass it through the screen. Place the wool fibers in a 250-ml beaker and again pass the powdered cellulose through the screen with but little pressure; place the short wool fibers obtained from this second screening operation in the beaker with those of the first and add sufficient hot $\left(70\right.$ to $\left.80^{\circ} \mathrm{C}\right)$ water to wet them thoroughly. Collect the fibers on a suitable filter as in (5) and agitate them with about 100 times their weight of a solution of hydrochloric acid prepared by diluting 1 part of the concentrated laboratory acid with 9 parts of distilled water. Collect the fibers and wash them with hot distilled water until the wash water gives no test for chlorides with a solution of silver nitrate. Dry to constant weight $\mathrm{F}$. The percentage of wool protein in the oven-dried specimen is $100 \mathrm{~F} / \mathrm{A}$, and the percentage of cotton is 100 $(E-F) / A$.

\section{ALTERNATIVE METHOD FOR DETERMINATION OF COTTON}

Place the specimen from (6) in a boiling 5 -percent aqueous solution of potassium hydroxide (previously boiled to remove dissolved air) for 10 minutes; sufficient solution is required to keep the fibers covered during the treatment. Filter the solution, and collect the fibers as a pad. Wash the fibers with hot distilled water, then with 5-percent aqueous solution of acetic acid, and then with distilled water until the wash water is neutral to litmus. Remove the fibers and dry them to constant weight $G$. The percentage of cotton cellulose in the oven-dried specimen, is $100 \mathrm{G} / \mathrm{A}$. 


\section{ANALYSIS OF SPECIMENS OF KNOWN COMPOSITION}

In order to determine the probable accuracy of the results obtained by the method, portions weighing about $1 \mathrm{~g}$ each of the fibers prepared in the manner described in section II were dried to constant weight in an electric drying oven. Specimens of the fibers were subjected to the procedure for removing size and finishing materials described in section IV-3, and then to the treatments prescribed for the separation of the kinds of fibers.

TABLE 1.-Effect of reagents used to dissolve some fibers on the weight of those considered insoluble

[Samples 1 to 4 were treated for 1 hour at $70^{\circ} \mathrm{C}$ with calcium thiocyanate, sp gr 1.20 at $70^{\circ} \mathrm{C}$, acidified with acetic acid. Samples 5 to 27 were similarly treated, but thiocyanate of sp gr 1.33 to 1.35 at $70^{\circ} \mathrm{C}$ was used.]

\begin{tabular}{|c|c|c|c|c|c|}
\hline \multicolumn{3}{|c|}{ VISCOSE } & \multicolumn{3}{|c|}{ MERCERIZED COTTON } \\
\hline Sample & Present & Found & Sample & Present & Found \\
\hline 3 & $\begin{array}{r}\text { Percent } \\
100.0 \\
100.0 \\
100.0 \\
100.0\end{array}$ & $\begin{array}{r}\text { Percent } \\
99.0 \\
99.3 \\
99.1 \\
99.4\end{array}$ & 7 8 & $\begin{array}{r}\text { Percent } \\
100.0 \\
100.0\end{array}$ & $\begin{array}{r}\text { Percent } \\
97.7 \\
98.2\end{array}$ \\
\hline \multicolumn{3}{|c|}{ COTTON } & \multicolumn{3}{|l|}{ WOOL } \\
\hline 6 5 & $\begin{array}{l}100.0 \\
100.0\end{array}$ & $\begin{array}{l}98.7 \\
98.7\end{array}$ & 10 & $\begin{array}{l}100.0 \\
100.0\end{array}$ & $\begin{array}{l}98.5 \\
99.3\end{array}$ \\
\hline \multicolumn{3}{|c|}{ VISCOSE } & \multicolumn{3}{|l|}{ WOOL } \\
\hline \multirow{3}{*}{1112} & \multirow{3}{*}{$\begin{array}{l}51.6 \\
49.3 \\
48.3 \\
49.2 \\
48.9 \\
48.7 \\
51.7 \\
50.3 \\
49.8\end{array}$} & \multirow{3}{*}{$\begin{array}{l}51.3 \\
49.9 \\
48.5 \\
49.4 \\
49.0 \\
49.0 \\
52.1 \\
50.6 \\
51.1\end{array}$} & (n) & 48.4 & 48.7 \\
\hline & & & \multicolumn{3}{|l|}{ COTTON } \\
\hline & & & \multirow{2}{*}{12} & $\begin{array}{l}50.7 \\
51.7\end{array}$ & $\begin{array}{l}50.1 \\
51.5\end{array}$ \\
\hline \multicolumn{3}{|c|}{ VISCOSE (Lilienfeld) } & & $\begin{array}{l}51.3 \\
48.3\end{array}$ & $\begin{array}{l}51.0 \\
47.9\end{array}$ \\
\hline 20 & $\begin{array}{l}48.6 \\
47.3\end{array}$ & $\begin{array}{l}49.0 \\
47.7\end{array}$ & \multicolumn{3}{|c|}{ MERCERIZED COTTON } \\
\hline \multicolumn{3}{|c|}{ CUPRAMMONIUM } & 18 & $\begin{array}{l}49.7 \\
50.2\end{array}$ & $\begin{array}{l}49.4 \\
48.9\end{array}$ \\
\hline - & $\begin{array}{l}50.8 \\
51.3\end{array}$ & $\begin{array}{l}51.8 \\
52.2\end{array}$ & 24 & $\begin{array}{l}49.2 \\
48.7 \\
49.7\end{array}$ & $\begin{array}{l}48.2 \\
47.8 \\
48.8\end{array}$ \\
\hline \multicolumn{3}{|c|}{ NITROCELLULOSE } & & & \\
\hline $24 \ldots \ldots$ & 50.3 & 51.2 & \multicolumn{3}{|l|}{ COTTON } \\
\hline 250 & $\begin{array}{l}49.4 \\
49.3 \\
50.4\end{array}$ & $\begin{array}{l}50.5 \\
49.6 \\
49.8\end{array}$ & $26-\ldots$ & $\begin{array}{l}50.7 \\
49.6\end{array}$ & $\begin{array}{l}50.4 \\
50.2\end{array}$ \\
\hline
\end{tabular}


Table 1 shows the effect of the treatments necessary to remove soluble fibers from those considered insoluble when treated by the procedure of section IV. Samples 1 to 4 were treated in the manner specified to dissolve silk, and the results show the loss of weight to be expected when ordinary viscose fibers alone are subjected to this treatment. Samples 5 to 27 were treated to dissolve regeneratedcellulose fibers, and the results show the amount of cotton, mercerized cotton, and wool recovered when treated alone or in mixtures with rayon. Table 2 gives the results of analyses of prepared specimens containing approximately 20 percent each of cellulose-acetate rayon, silk, regenerated-cellulose rayon, mercerized cotton, and wool. Cotton and wool were determined by using a solution of aluminum chloride and heating for removing the cotton, and a boiling solution of potassium hydroxide for removing wool.

TABLE 2.-Results of analyses of known mixtures of purified cellulose-acetate rayon, silk, regenerated-cellulose rayons, mercerized cotton, and wool fibers

[Specimens were treated to remove size and finishing materials, then with acetone, acidified calcium thiocyanate of sp gr 1.20, acidified thiocyanate of sp gr 1.35, and aluminum-chloride or potassiumhydroxide solution]

\begin{tabular}{|c|c|c|c|c|c|c|c|c|c|c|}
\hline \multirow{2}{*}{ Specimen } & \multicolumn{2}{|c|}{$\begin{array}{l}\text { Cellulose-ace- } \\
\text { tate rayon }\end{array}$} & \multicolumn{2}{|c|}{ Silk } & \multicolumn{2}{|c|}{$\begin{array}{l}\text { Regenerated- } \\
\text { cellulose rayon } \\
\text { (viscose) }\end{array}$} & \multicolumn{2}{|c|}{$\begin{array}{l}\text { Mercerized } \\
\text { cotton }\end{array}$} & \multicolumn{2}{|c|}{ Wool } \\
\hline & Present & Found & Present & Found & Present & Found & Present & Found & Present & Found \\
\hline $1, \ldots$ & $\begin{array}{l}\% \\
21.6 \\
20.7\end{array}$ & $\begin{array}{l}\% \\
21.6 \\
20.7\end{array}$ & $\begin{array}{l}\% \\
21.3 \\
19.8\end{array}$ & $\begin{array}{l}\% \\
21.8 \\
20.4\end{array}$ & $\begin{array}{l}\% \\
19.8 \\
19.2\end{array}$ & $\begin{array}{l}\% \\
20.3 \\
20.0\end{array}$ & $\begin{array}{l}\% \\
19.4 \\
19.9\end{array}$ & $\begin{array}{r}\% \\
\text { × } 18.2 \\
17.9\end{array}$ & $\begin{array}{l}\% \\
17.9 \\
20.4\end{array}$ & $\begin{array}{l}\% \\
18.0 \\
+21.1\end{array}$ \\
\hline
\end{tabular}

VISCOSE (LILIENFELD)

\begin{tabular}{l|r|r|r|r|r|r|r|r|r|r}
\hline $3 \ldots \ldots$ & 19.3 & 19.2 & 20.2 & 20.6 & 19.5 & 20.1 & 21.7 & a 21.5 & $\begin{array}{r}19.3 \\
19.9\end{array}$ & $\begin{array}{r}18.6 \\
19.6\end{array}$ \\
\hline
\end{tabular}

CUPRAMMONIUM

\begin{tabular}{|c|c|c|c|c|c|c|c|c|c|c|}
\hline 6 & $\begin{array}{l}21.6 \\
21.2\end{array}$ & $\begin{array}{l}21.3 \\
21.0\end{array}$ & $\begin{array}{l}20.1 \\
20.2\end{array}$ & $\begin{array}{l}20.7 \\
20.7\end{array}$ & $\begin{array}{l}18.7 \\
19.3\end{array}$ & $\begin{array}{l}19.2 \\
20.0\end{array}$ & $\begin{array}{l}20.1 \\
18.9\end{array}$ & $\begin{array}{l}320.0 \\
19.4\end{array}$ & $\begin{array}{l}19.6 \\
20.4\end{array}$ & $\begin{array}{r}18.9 \\
\text { b } 18.8\end{array}$ \\
\hline
\end{tabular}

NITROCELLULOSE

\begin{tabular}{|c|c|c|c|c|c|c|c|c|c|c|}
\hline $\begin{array}{l}7 \\
8 \\
9\end{array}$ & $\begin{array}{l}20.2 \\
20.0 \\
20.1\end{array}$ & $\begin{array}{l}20.3 \\
20.0 \\
20.2\end{array}$ & $\begin{array}{l}20.3 \\
21.0 \\
20.3\end{array}$ & $\begin{array}{l}21.8 \\
22.3 \\
21.0\end{array}$ & $\begin{array}{l}20.0 \\
19.0 \\
19.7\end{array}$ & $\begin{array}{l}19.4 \\
19.4 \\
20.3\end{array}$ & $\begin{array}{l}19.7 \\
19.8 \\
19.9\end{array}$ & $\begin{array}{r}19.4 \\
20.3 \\
18.9\end{array}$ & $\begin{array}{l}19.8 \\
19.2 \\
19.9\end{array}$ & $\begin{array}{r}19.2 \\
17.8 \\
\text { b } 19.6\end{array}$ \\
\hline
\end{tabular}

a Determined by difference, using aluminum-chloride method.

b Determined by difference, using potassium-hydroxide method.

The results given in the table show that in a mixture containing cellulose-acetate rayon (acetone-soluble type), silk, regeneratedcellulose rayon as nitrocellulose, viscose, cuprammonium, or Lilienfeld rayons, wool, and cotton or mercerized cotton, the amount of each kind of fiber can be determined by the method within 2 percent of the weight of the specimen analyzed.

Washington, May 31, 1935. 